Article

\title{
Impact of Farmers' Associations on Household Income: Evidence from Tea Farms in Vietnam
}

\author{
Hung Van $\mathrm{Vu}^{1, *}$, Huong $\mathrm{Ho}^{2}$ and Quoc Hoi Le ${ }^{3}$ \\ 1 Faculty of Political Theory, Thuongmai University, Hanoi 100000, Vietnam \\ 2 Faculty of Politics, Vietnam Youth Academy, Hanoi 100000, Vietnam; hohuong112007@gmail.com \\ 3 Journal of Economics and Development, National Economics University, Hanoi 100000, Vietnam; \\ hoilq@neu.edu.vn \\ * Correspondence: hungvvu@tmu.edu.vn
}

Received: 3 August 2020; Accepted: 1 October 2020; Published: 26 October 2020

check for updates

\begin{abstract}
Farmers' associations play an important role to help members increase their access to supports of information, capital, and technology; bring benefits to members; and partly promote production, enhance productivity, and increase income. This paper systematizes the theoretical foundation and empirical evidence on income difference between the member and non-member farmers and identifies factors that affect their decisions to join associations. By comparing specific characteristics between the member and non-member farmers, the paper examines the impact of joining farmers' associations on the income of tea farmers in Vietnam by using the data from the survey of 742 farms. In our sample, 376 respondents are members and 366 non-members of associations in the four largest tea-producing areas, which cover 30 provinces in Vietnam. The paper uses OLS regression model to identify the factors that influence the decision of tea farms to join farmers' organizations and tobit model to assess more detailed impacts of membership on income. The findings show that the farmers, who are members of an association, are more helpful in the ability to access better market services and more tea prices, and are more likely to earn a higher average income than those are non-members. Moreover, their memberships result in an increase of 0.166 unit of income. The research results also show that other factors, including labor, tea price, share of tea sold, farmer age, tea area, ability to access extension services, and credit services, affect the farmer's income.
\end{abstract}

Keywords: membership; OLS; tobit; Vietnamese Tea Association (VITAS)

JEL Classification: D13; H31; J51

\section{Introduction}

In Vietnam, tea is considered more highly effective than other products to eliminate hunger and reduce poverty and contribute to developing the local economy. In 1999, the government recognized the tea industry as one of 10 strategic exporting products and approved the industry planning from 2000 to 2010. Since then, the industry has reached some milestones. In 2018, 128,000 tons of teas were exported, with the revenue of 219 million USD. In 2019, 500,000 tons of dried leaves were produced, 130,000 ha cultivated, 400,000 farms, 500 producing and processing units, and created over 1.5 million new jobs annually (General Statistics Office of Vietnam (GSO) 2019).

Few tea varieties have a high yield and outstanding quality in some regions, which have become tea brand names, i.e., Tan Cuong, Moc Chau, and Bao Loc. International economic integration creates opportunities to diversify broad categories to meet the demand of domestic and overseas consumers, e.g., dried and shaped tea leaves, green tea, Oolong tea, scented tea, herbal tea, and new tea varieties such as Bat Tien and Ngoc Thuy. The domestic market has niches for four tea products, namely green 
tea, black tea, Oolong tea, and fresh tea leaves. The opportunities can enable producers to replace the complete growing region of raw materials or built a joint-venture company with foreign counterparts, extend larger market share, and learn more techniques and technologies.

However, the industry has been coping with several enormous challenges to extend the exporting markets, i.e., most of the countries growing and exporting tea products have a higher level of technology, quality, and food safety; exporting markets require increasingly higher quality; the growth in demand is slower than supply; local producers are strongly competed by the foreign enterprises; meanwhile, tea farms mostly are smallholdings who have low labor productivity and scattered growing areas.

To adapt to the integration process as well as build up a capability to export a large volume with a higher economic value, farmers need to find unique solutions, including becoming a member of associations (Do 2013). Associations support tea farmers in promoting exports to foreign markets, strengthening and extending the domestic markets; create communication channels about markets and customers with their members; identify cooperation strategies, joint-venture and collaboration in producing and selling based on the voluntary basis of all members; protect the rights of members in the legal cases of trade dumping and anti-dumping; reflect truthful members' opinion on development plans; cooperate between Vietnamese and international associations in a specific product; strengthen the coordination between ministries, industries, and associations in performing the duty of socioeconomic development, complying with all WTO (World Trade Organization) commitments (Tran 2008).

In Vietnam, the legal frame for the Vietnamese Tea Association (VITAS) remains vague; this does not enable the favorable conditions to develop associations. There is a lack of specific regulations on food/commodity supply chain associations, management is overlapping, and member spatial distribution is insufficient along the supply chain to manage the arm-length network (Nam 2017). As a result, in some regions, associations cannot promote their roles. Because associations have blurred activities, tea farmers do not recognize the active role of association as a farmer's aid. In most regions, farmers are not aware of the positive benefit of joining the association (Chung and Cuc 2018). Because of the lack of support in technology, capital, and market, the efficiency of non-members is likely to be lower. This situation has led to many farms removed from valuable-gene and old-ageing tea plants shifted to grow other plants, which can cause a waste of producing resource, forest erosion, and re-poverty (Pham 2017). Some other farmers have transferred from tea farming into other agricultural activities, such as growing citrus plants, bonsai plants, and vegetables; aquaculture; and rearing animals for food. However, farmers have not improved their revenues and incomes, because of surplus supply, limited demand, and diseases (Oxfarm 2017).

The objective of this study is to determine the impact of farmers' associations on a household income of tea farms in Viet Nam. To do so, this study adopts the following research objectives:

- It aims to systematize the theoretical foundation and empirical evidence on income difference between the member and non-member farmers.

- It aims to identify factors that affect their decisions to join associations. Furthermore, by comparing specific characteristics between the member and non-member farmers, the study analyzes and evaluates the impacts of membership on the income of farmers. From our findings, we recommend that farmers be more active and join an association, whereas association should strengthen their positive roles in supporting tea farmers to improve their producing resources and, hence, increase their incomes.

\section{Literature Review}

Becoming a member of associations can be considered as one of the important factors to help farmers increase their access to supports of information, capital, and technology and bring benefits to farmers and partly promote production and enhance productivity (Adewakun 2012; Bachke 2009; Bernard et al. 2008; Muchopa 2011).

In general, benefits of the association's membership to farmers are often researched in terms of creating opportunities for their members to gain access to agricultural credit schemes and 
support services, market information, and management knowledge (Hellin et al. 2009; Mwaura 2014). Baah (2008) proved that associations from the cocoa industry in Ghana could help farmers to strengthen possibilities to access credit loan and market information, as well as gain awareness of policies and services. These helpful supports enable farmers to free from the cycle of low productivity and income. Besides, associations encourage farmers to join programs of agricultural and rural development; consequently, these can bring significant benefits for farmers in Loko region, northern Sierra (Mohamed and Mansaray 2016).

Alternatively, according to (Sheilla et al. 2015), farmers' associations help members via cooperative business activities, which, in turn, improve the livelihood for farmers in rural areas of sub-Saharan Africa (Kenya and East Africa). Membership of associations can help farmers to get benefits in both socio and economic aspects through joining the group activities from their associations (Ates and Terin 2011; Fisher and Qaim 2012). This finding was echoed by Simonović (2016), when 28.2\% interviewed farmers confirmed that memberships help them to gain remarkable benefits.

Similarly, according to (Ho 2014), in the context of fierce competition, there are requirements to have a large volume of products with high quality, meet the international standard, on-time delivery, competitive selling price, and cannot be capable of a farmer. Therefore, joining associations can help farmers to get supports of capital, technology, and technique, especially to ensure a stable selling market. These activities can create collaboration among members to satisfy better the vivid market demand and build closer teamwork when working together. Le (2005) showed that collaboration among farmers is proved as one of the most effective methods to overcome the limitation of capital and technology.

The effective operation of associations can create opportunities for farmers to get a position in the market and get the benefits. Income increase is the primary motivation for farmers to join these associations; if this expectation cannot be ensured, it will influence the decision of being a member (Nguyen and Trinh 2011; Nguyen et al. 2010). Similarly, Tran (2017) argued that one of the best solutions for producers is to increase capital for production or joining associations.

Most previous studies have used the linear regressive model to examine the impact of farmers' associations to changes in livelihood and household income. Ekepu and Tirivanhu (2017) used a binomial logit regression model to test the role of associations and socioeconomic factors that influence the income of sorghum bicolor farmers in Uganda. Membership can help households to approach some services, e.g., credit loan, market access, and management training. Moreover, other researchers have used the tobit regressive model to examine the role of association to the production efficiency, productivity and income of a household. In particular, Van Hung et al. (2019) used this model to estimate impact factors to the production efficiency of rice farming. They concluded that membership enables farmers to gain more knowledge and experience through sharing and gaining additional information, which can help improve their production efficiency.

Some studies have applied OLS to examine the impact of membership and socioeconomic factors on the income of farmers in rural Anambra, Nigeria (Nkechi and Charles 2015), whilst Taiwo (Abdulahi et al. 2015) studied the impact of membership to transfer the economic rights to women in Osun State, Nigeria. Sampled data were analyzed by both descriptive statistics and inferential model of regression, $t$-test, ANOVA non-parametric correlation test, and post hoc test. Research findings indicated that an increase in income of interviewees is a determinant factor to become a member of a cooperative in the case the household head is female. By applying the same t-test model, (Gomina 2013) estimated the positive impacts from the credit supports from associations for hunger elimination and poverty reduction, and increased income for plant farmers in Nigeria through paired t-test and multiple regressions.

Furthermore, a few studies have used the regressive probit model to estimate how membership can influence household incomes (Tolno et al. 2015; Ebrahim et al. 2020; Mpiira et al. 2013). Mpiira et al. (2013) has applied the regressive probit model to calculate the changes in the income when association members can get a loan from the program of the Savings and Credit Cooperative 
(SACCO) sponsored by cooperatives in Uganda. This research confirmed that the benefit from these preferential programs makes the income of members more and more stable. However, the research also noted that SACCO programs were often relevant to members who have low income rather than who have wages and high financial demands, which were not satisfied by SACCO. Regarding financial issues of household farms in agriculture, Valaskova et al. (2020) has applied bankruptcy models examined in the agricultural section in Slovak economy. The authors have tested the financial stability from household farms and proposed some recommendations to mitigate the hidden financial risk and improve the management method.

The similar observation has been done from vegetable farmers in Habru district, Northern Wollo, Ebrahim et al. (2020). His findings noted that plants play an important role in improving household income in Ethiopia. Nevertheless, the choice of output market to match the expectation of increase benefits of households is the key challenge to vegetable farmers in this district. The study has used both descriptive and multivariate probit methods to analyze sampled data. The research conclusion implied that the farmers' association need to promote the methods to seek market information, financial support, delivery support, training methods, and experience-sharing among the vegetable farmers to promote production and, hence, raise productivity and increase income for these households in the region.

In contrast, Idowu and Oladeji (2019) applied the probit model to calculate levels of impact from cooperatives to income and livelihood of stock farms (goat, sheep, poultry, pig, and catfish). He proved the income coefficient has a negative relation with the membership of cooperatives and significant meaning of $10 \%$. This finding applies to the belief that farmers with low credit are often more willing to join associations hoping to get substantial benefits from their membership. He recommends that, to extend aid role, the association should combine both training farming knowledge and provide short-term loans, and provide market information to increase the ability to access to credit scheme, techniques, and help to increase income for members, who mostly have limited capital and low capability of production.

In Vietnam, to evaluate the role of association to the household's income, some studies have used the linear regressive model; however, they only examine one aspect of impacts from membership (Le 2014; Van Hung et al. 2019). To the best of our knowledge, there are few studies used three OLS and probit, tobit models to estimate the impact of memberships to the income of tea farmers. Therefore, in this study, we apply different regressive models to examine how memberships influence the income of tea farms. Specifically, OLS is used to identify determinant factors for decision of joining associations, whereas tobit model used for the dependent variable is the ratio of net farm profit to revenue score (E/A) to estimate how membership affect to the income of tea farmers.

\section{Research Area, Data and Methods}

\subsection{Research Area}

By 2019, tea plant trees have grown throughout the North, Central and South on four ecological regions: Red River Delta, Northern Midlands and Mountains, North Central and Central Coast, and Highlands, which cover over 30 provinces in Vietnam. Tea-growing zones are mostly in 14 Northern midland provinces with an area of 92.2 thousand hectares, accounting for $72 \%$ of the country's tea area. Some provinces have large tea-growing zones such as Lam Dong (17.1\%), Ha Giang $(15.4 \%)$, Thai Nguyen (14.9\%), Phu Tho (12.5\%), Yen Bai (9.1\%), and Tuyen Quang (6.5\%).

The growing tea area in these six provinces has accounted for nearly $60 \%$ of the total area in Vietnam. In particular, Lam Dong province has had the largest one of 22,000 ha. It also has a high speed of developing tea-growing area. In these six provinces, they consider tea farming as a primary job for most of the local labor force; thus, the number of members is the highest in nationwide. Therefore, when authors have set the research focus in this region, it will enable researchers to capture a good understanding of the role of farmers' associations to improve income when becoming a member. 


\subsection{Farmers' Associations in the Tea Industry}

Currently, there are three farmers' associations in the tea industry, i.e., Vietnamese Tea Association (VITAS), Vietnamese agricultural association, and Vietnamese cooperation alliance.

\subsubsection{Vietnamese Agricultural Association or Vietnamese Farmers' Association}

This is a sociopolitical organization, established in 1930, and is under the umbrella of the Vietnamese government. The organization's objectives are to consolidate farmers and strengthen the working class of farmers in all aspects; become a reliable force in alliance among workers, farmers, and intellectuals to conduct successfully the process of industrialization, agricultural, and rural modernization; gather a majority of farmers into the association; extend and improve the quality of membership; train responsible staff to meet the needs and duties of industrialization and modernization; expand the range of legal activities; and promote cooperations, exchange, and create forums for sharing experiences, new technologies and techniques, and advertising new tea products.

After becoming a member, tea producers will get support in business credit loans, supplying agricultural equipment, tools, and materials. Furthermore, producers will have access to new technologies and techniques through the training workshops, as well as have a chance to develop brand names for their products.

\subsubsection{Vietnamese Tea Association (VITAS)}

This association is a voluntary basis for citizens and organization in the same industry and interests; share the common aims to gather and unite members, operate regularly, non-profitable; to protect rights and legal benefits for the association, members, and community; and support each other, to play effectively.

Under the current regulation, employment association is a social, job-related organization and has a legal status, has a stamp, and their business bank accounts (domestic and foreign currencies); organize and operate based on a voluntary basis, self-management, self-responsibilities, and self-funding corresponding to Vietnamese regulations and associations' rules approved by authorized agencies.

In the international integration process, employment associations have proved their roles in connecting and supporting trading. In the stage of selling tea, many tea farmers have faced challenges to access to the domestic and overseas markets, especially the latter, when they have to break down all the markets' barriers, e.g., high standards of quality, food safety, and technology. Meanwhile, their memberships enable them to receive the advisory information, the updated market situation as well as the relation between supply and demand, guidance, warning notice to producers, introducing of specific potential markets, and forecasting about rivals.

On the other hand, employment associations play an important role in horizontal and vertical supply chains in the economy. Based on these networks, producers will collaborate to develop a better supply chain, which is from producing and processing to selling, provides more equal benefit-division for all stakeholders.

\subsubsection{Cooperatives in the Tea Industry}

Cooperative (co-op) in the tea industry is a business organization, whose ownership belongs to a group of individuals based on their common benefits. A co-op is also defined as an enterprise owned and controlled by a group using services provided by the co-op staffs or members.

Through the agricultural co-op mechanism, members can interdepend, support each other, and gain access to desired types of markets for raw materials, fuel, input materials, services, and outputs. Members can be benefited from products and services provided by their credit co-ops, advised information, and shared experiences through agricultural co-ops. The most important function of co-ops is to create new jobs for members, who are benefitted by receiving dividends as a shareholder and are eligible to vote and make decisions of business policies via management levels. 
Therefore, in Vietnam, each smallholder can take part in one or multiple associations, depending on their condition case by case and their business objectives. All associations provide support services from sourcing raw material input, seeking capital, and technology; trading method and finding new markets. However, each association has its unique individual advantages. VITAS is strong in connecting, supporting in trading and members to become a stakeholder in the supply chain. All aid and the right protection for members are based on a voluntary and non-profit basis (see Appendix A Table A1).

In the meantime, Vietnamese farmers' association, which is a sociopolitical organization managed by the government, whose major activity is providing supports for tea farmers in terms of capital, techniques, information, and training workshops. Additionally, the association can provide members credit loans through some other programs, for instance, the program to develop new rural zones or the preferential programs to develop agriculture sponsored by Vietnam Bank for Social Policies. However, this association is a governmental agency; as a result, a maze of bureaucracy has caused a delay in the timeframe and complicated to process applications.

Apart from its two counterparts, tea co-op is an economic organization owned by its members, who aim at the principal objective is creating not only new jobs for its members but also more beneficial conditions for producing and processing. A co-op is organized as a shareholder company, in which all members will receive a profit share based on the company's revenue and its shareholders.

\subsection{Data}

Our main information for the analysis was got from a survey of tea producers in four major tea producing areas in Vietnam, namely Red River Delta, Northern Midlands and Mountains, North Central and Central Coast, and Highlands with the provinces have large tea-growing zones such as Lam Dong, Ha Giang, Thai Nguyen, Phu Tho, Yen Bai, and Tuyen Quang. We select these provinces because they are ones of the most important tea-growing areas in Vietnam.

The regions were purposely chosen because they are the major tea-producing areas in Vietnam, with identifiable producer associations, and, most importantly, they have one of the most successful farmers' association. We selected the study areas purposely based on their tea productivity to obtain a sample of individual producers; this was also driven by contextual circumstances and the need to ensure that an important number of tea growers would be identified in a random sample.

To get a sample of members of farmers' associations, we drew a random sample of registered farmers of associations from a complete list in each area, and we then selected farmers from among the listed members. To assure the sample representation of survey data, at each studied province, we select two districts; in each district, we select three communes; in each commune, we choose 20 farmers, except for 22 farmers per commune in Lam Dong because this province has a denser spatial distribution of tea farmers and favorable survey conditions. We select interviewees from those with the largest growing area list supplied by local authorities.

A semi-structured and structured questionnaire was used to collect data from members and non-members of farmers' associations among the smallholder tea producers. Face-to-face interviews were conducted with 742 tea producers (376 farmers' association members and 366 non-members) to collect information on the farm economy, farming practices, as well as the social and economic characteristics of the farm household. Key informants' interviews and focus group discussions were then conducted; secondary data was synthesized from the literature review and reports from the Vietnamese Ministry of Agriculture, Vietnamese Tea Association, General Statistics Office of Vietnam (GSO).

\subsection{Methods}

To estimate the impacts of joining associations on the household income of potato farmers in Middle Guinea, Emmanuel (Tolno et al. 2015) have applied OLS and probit models with 3 variables groups of household wealth, capacity and information, household demographics. In this study, we use the OLS with these variables to examine the impacts of association membership on the household 
income of tea farmers. Besides, based on the specific features of the tea plant are a perennial and grown in midland and mountain areas, therefore, more variables are added, i.e., tea age, experience, ethnicity, Communist Party membership, and region.

The OLS regression method to show the factors that influence the decision of tea farmers to join farmers' associations. However, some unobserved factors also influence the decision to become a member. If this occurs, the result of OLS can generate a biased parameter as estimating the simple regression analysis of farm income based on dichotomous variable associated with membership will overvalue how much membership will affect to farm income. Therefore, the model used to identify factors that influence the decision of tea farms to join farmers' associations:

$$
P_{(1,0)}=\alpha Z_{i}+\varepsilon_{i}
$$

where $\alpha$ is constant, $P$ is a dummy variable ( 1 for association member and 0 for non-member), $Z_{i}$ is a set of respective observed factors expected to influence decision to join farmers' associations, and $\varepsilon_{\mathrm{i}}$ is the group of individual examined factors expecting influence a decision to become a member.

Second, from the selection equation, we use a tobit model with the dependent variable as the ratio of E/A to estimate the effect of association membership:

$$
Y i=\beta X_{i}+\varphi P_{i}+\mu_{i}
$$

where $Y_{i}$ is the impact outcome variable (gross farm income in VND/ha) for producers; $X_{i}$ is a vector of independent variables affecting income; $P_{i}$ is a binary variable representing association membership; $\beta, \varphi$, and $\delta$ are parameter vector to be estimated; and $\mu \mathrm{i}$ is a normally distributed random error term.

The first group of variables is household assets, farm size, land ownership, growing area, and off-farm income. We use these variables in the analysis for the wealth of household, which is likely to enable farmers to meet requirements to become a member. The second group includes variables on household capacity and information, e.g., education, tea age, hire labor, experience, extension services, credit access, and association membership, and it is used to test the production capacity of the household. The third group involves the demographic variables, i.e., family size, gender and age of head, and family labor. Last, the fourth group is for regions (see Table 1). Location of tea farm might influence a decision of joining association because each region has different natural conditions and business styles.

Table 1. Definition of explanatory variables used in the regression models.

\begin{tabular}{cccc}
\hline Variables & Definition & Mean & SD \\
\hline Association membership & Membership in tea farmers association $(1=$ yes; $0=$ no) & 0.51 & 0.500 \\
\hline Age & Farmer's actual age (years) & 37.59 & 5.960 \\
\hline Gender & Respondent gender $(1=$ male; $0=$ female) & 0.82 & 0.383 \\
\hline Education & Actual schooling years & 10.99 & 2.382 \\
\hline Ethnicity & Whether respondent is Kinh $(1=$ yes; $0=$ no) & 0.54 & 0.498 \\
\hline Family size & Number of household members (people) & 4.93 & 0.548 \\
\hline Family labor & Family members working on the farm (people) & 3.84 & 0.660 \\
\hline Land ownership & Whether respondent owns farm land (1 = yes; $0=$ no) & 0.55 & 0.498 \\
\hline Farm size & Household's total arable land (ha) & 0.76 & 0.788 \\
\hline Experience & Years of growing tea & 12.63 & 5.054 \\
\hline Tea age & Years of tea plant & 20.47 & 7.977 \\
\hline Tea area & Tea production area (ha) & 0.74 & 0.798 \\
\hline Distance to road & Distance from farm to main road $(\mathrm{km})$ & 1.50 & 0.234 \\
\hline Labor used & Hired labor (man-day/ha) & 5.15 & 5.839 \\
\hline Extension access & Access to extension service (1 = yes; $0=$ no) & 0.52 & 0.500 \\
\hline
\end{tabular}


Table 1. Cont.

\begin{tabular}{|c|c|c|c|}
\hline Variables & Definition & Mean & SD \\
\hline Distance to market & Distance to primary market $(\mathrm{km})$ & 2.50 & 0.323 \\
\hline Share of tea sold & Quantity of tea sold to totally harvested (percent) & 77.97 & 13.778 \\
\hline Tea price & Tea market price (VND/kg) & 20.24 & 5.281 \\
\hline Farm income & Gross farm revenue (VND/ha) & $35,586.560$ & $44,545.430$ \\
\hline Credit access & Access to farm inputs credit $(1=$ yes; $0=$ no $)$ & 0.51 & 0.500 \\
\hline Off-farm income & Income from non-farm activities (VND) & 2306.12 & 2162.577 \\
\hline Communist party & Membership in Communist party $(1=$ yes; $0=$ no $)$ & 0.48 & 0.500 \\
\hline Red River Delta & Tea farms in this area $(1=$ yes; $0=$ no $)$ & 0.14 & 0.355 \\
\hline $\begin{array}{l}\text { Northern Midlands and } \\
\text { Mountains }\end{array}$ & Tea farms in this area $(1=$ yes; $0=$ no $)$ & 0.30 & 0.459 \\
\hline $\begin{array}{l}\text { North Central and } \\
\text { Central Coast }\end{array}$ & Tea farms in this area $(1=$ yes; $0=$ no $)$ & 0.14 & 0.352 \\
\hline Highlands & Tea farms in this area $(1=$ yes; $0=$ no $)$ & 0.40 & 0.491 \\
\hline
\end{tabular}

\section{Results and Discussion}

\subsection{Descriptive Statistics and Findings}

We present the findings showing the characteristics of tea farmers in Appendix A Table A2. The average farm size is $0.76 \mathrm{ha}$, of which $97 \%$ used for growing tea. This closely reflects the status of the farming area in Vietnam with the overall average size is 0.5 ha. Men are dominant $(82.1 \%)$ in the studied sample, with an average age of 37 years old, and 90\% married. More than half of surveyed farmers have their land ownership and gain access to extension service and credit schemes. When we compare the socioeconomic household characteristics between member and non-member, there are insignificant differences (see Appendix A Table A2).

Generally, results in Appendix A Table A2 show that characteristics of the two groups do not have statistical significance, except age, gender, and ability to gain access to extension services and credits. The average age of the association member is 47.65 , while that of a non-member is 36.52. Most members are Kinh and live in Northern Midlands and Mountains and North Central and Central Coast. The difference has a statistic significance $(p<0.05)$.

The difference between the two groups is insignificant regarding the tea age because tea plants generally reach their maximum yield from 10 to15 years old. However, the member farmers have two more years of growing experience in.

Similarly, there is a significant difference in accessing credit and agricultural services. Most association members have gained access to agricultural credit services $(94.7 \%)$ and support services from agricultural staff $(82.6 \%)$. In the meantime, those rates from non-member are $17.4 \%$ and $14.8 \%$, respectively. In general, these support services will create more opportunities for tea farms. In Vietnam, training courses or workshops are often organized by local farmers' association at neighborhood areas. The credit schemes are mainly aided by the Vietnam Bank for Social Policies.

The surveyed results show that farmers who have memberships can get benefits from support services provided by associations. There is only a small percentage of members (5.3\%) have not gained access to support services from agricultural staff. Lastly, results in Appendix A Table A2 indicate that physical assets are not the decisive factors for joining association because there are no significant differences associated with family labor, farm size, and tea cultivation areas found between the two groups.

The estimation of crop profitability between the two categories of producers is presented in Table 2. Based on net farm profit, the estimation of crop profitability between the two categories of 
producers is presented in Table 2. In terms of net farm profit, estimation of profit between members and non-members are not much different. In Table 2, the highest costs of tea household are for fertilizers and labor, 35\% and 54\%, respectively. Other operational costs (tools and equipment hire, premises hire) have a gap between the two groups with $7.9 \%$ for members and $6.8 \%$ for non-members. This gap results from the fact that association members are more easy to access to support services than those who are not members.

Table 2. Profitability estimation of tea production per ha.

\begin{tabular}{|c|c|c|c|c|}
\hline Characteristics & $\begin{array}{l}\text { Association } \\
\text { Members }\end{array}$ & Non-Members & $t$-Statistic & $p$-Value \\
\hline A. Farm revenue (VND) & $61,943.750$ & $45,834.39$ & 2.674 & 0.002 \\
\hline \multicolumn{5}{|l|}{ B. Variable input cost (VND) } \\
\hline Seed cost & 4.386 & 4.090 & 1.080 & 0.721 \\
\hline Fertilizer cost & 6831.830 & $10,744.09$ & -2.592 & 0.006 \\
\hline Other operational costs & 1306.780 & 2609.63 & 0.686 & 0.006 \\
\hline Labor cost & $10,382.970$ & $10,571.78$ & 1.995 & 0.120 \\
\hline Machinery cost & 601.532 & 2061.80 & 1.795 & 0.320 \\
\hline Total & $19,127.498$ & $25,991.390$ & 0.547 & 0.280 \\
\hline C. Fixed input cost (VND) & 3.757 & 3.270 & 0.889 & 0.001 \\
\hline D. Production cost $(B+C)$ & 6426.551 & $12,686.67$ & 0.940 & 0.002 \\
\hline E. Net farm profit (A-D) & $55,517.220$ & $33,147.73$ & 7.238 & 0.006 \\
\hline Ratio of revenue to cost (A/D) & 9.96 & 4.44 & & 0.001 \\
\hline Ratio of net farm profit to revenue (E/A) & 0.88 & 0.71 & & 0.003 \\
\hline
\end{tabular}

Source: author's survey (2019).

There is a remarkable gap in the cost of buying inputs between the two groups, hence the difference in their net profits. The net profit of a member is 1.67 times higher than that of a non-member. Moreover, because of the high input costs, the A/D and E/A are significantly different between the two groups. These ratios of members are 9.96 and 0.88 whereas those of non-members are 4.44 and 0.71 . In other words, the A/D of the member is more than double than that of non-member because association's member usually receives supports of seeds, labor, information, capital credit, training, and other inputs.

\subsection{Determinants of Association Membership}

OLS model used here to explain the expected variables influenced the farmers' decision to join associations. Of all the described variables as above, only ethnicity, education, experience, hired labor, distance to market, tea price, tea area, and land ownership significantly affect the decision of being a member $(p<0.05)$. In contrast, the other variables of age, gender, Communist party membership, tea age, off-farm income do not influence the decision (Table 3).

If the other factors are unchanged, the results of estimation affirm that education has a statistic meaning $(p<0.05)$; an increase of one school year will raise the willingness to join association 0.602 times. The more educated farmers are aware of potential benefits from membership and getting more support services. The willingness to join association continues to increase along with experience in growing tea. The experienced farmers are more aware of potential benefits from getting more support services. Moreover, the findings show that the Kinh are more likely to be a member than the other ethnic groups, who are hindered by barriers of language and cultural customs.

The expansion of farm size, hired labor and ownership will increase the willingness to become a member $0.126,0.144,0.276$, respectively. These factors play an important role as mentioned earlier, farmers are mostly shortage of capital while producing in a larger scale requires greater resources and capital; therefore, joining an association is one of the most effective strategies to overcome these constraints. 
Table 3. Determinants of membership in farmers' association.

\begin{tabular}{cccc}
\hline Variables & Coefficient & SE & $p$-Value \\
\hline Age & -0.242 & 0.0016 & 0.049 \\
Gender & -0.042 & 0.1109 & 0.070 \\
Education & 0.602 & 0.0043 & 0.009 \\
Hired labor & 0.144 & 0.0056 & 0.008 \\
Tea area & 0.130 & 0.2413 & 0.588 \\
Distance to the market & 0.351 & 0.0281 & 0.001 \\
Tea price & 0.218 & 0.0024 & 0.005 \\
Ethnicity & 0.123 & 0.0345 & 0.000 \\
Communist party & -0.943 & 0.0299 & 0.002 \\
Experience & 0.115 & 0.0022 & 0.008 \\
Tea age & 0.112 & 0.0013 & 0.934 \\
Land ownership & 0.276 & 0.0224 & 0.020 \\
Farm size & 0.126 & 0.2457 & 0.007 \\
Extension service & 0.397 & 0.0425 & 0.000 \\
Credit access & 0.390 & 0.4156 & 0.000 \\
Off-farm income & -0.001 & $6.31 \times 10^{-6}$ & 0.045 \\
Red River Delta & 0.276 & 0.0965 & 0.055 \\
Midlands and Mountains & 0.779 & 0.1007 & 0.040 \\
Northern & 0.680 & 0.0879 & 0.040 \\
North Central and Central Coast & 0.485 & 0.1016 & 0.033 \\
\hline Highlands &
\end{tabular}

Source: Author's survey (2019).

The ability to gain access to extension service has statistical significance and a positive impact on membership. This might result from the fact that associations provide information with better quality. The existing members can discuss with farmers about potential benefits, which, hence, influence to making decision process of tea farmers. Households, who have a closer connection to associations, are more easily to utilize the supports from the association; as a result, they increase their productivities and incomes. In summary, agricultural support services and cultivation advisory are crucial to smallholder farmers (Nguyen et al. 2019).

Credit access has statistical significance in estimated results from the model. The results show that credit access affects the decision of farmers to join an association. Similarly, Tran et al. (2018) reveal that credit access influence positively to making decision process of becoming a member of an association in Vietnam. Better credit access enables farmers to meet the required conditions of becoming a member.

Tea age, tea area, and tea cultivation in various regions can have a positive impact on farmers' willingness to become members at their local regions because the differences of natural conditions and effectiveness of local associations. For example, the two regions of Northern Midlands and Mountains, North Central and Central Coast, have favorable weather condition and terrain for tea plants; consequently, their local tea associations are strong and have a higher rate of members in tea farmers.

Nevertheless, gender and age influences negatively to join associations. That means the gender of the household head does not make a difference in their decision of joining an association. Furthermore, membership of the Communist Party also undermines the willingness of joining an association because most party members are working for the governmental offices; therefore, tea cultivation is only a minor job. This implies that, the more off-farm income a farmer has, the less willing he or she is to join associations.

\subsection{Effects of Membership in Farmers' Association on Farm Income}

After identifying the determinant factors on farmers' decision becoming a member, the authors examined the impact of membership on farmers' income. Tea farmers join associations mainly to get benefits from agricultural services (food processing, equipment hire, and up-skill training); however, 
they also expect their memberships to help them earn a higher income in tea-producing. The mean of the net profit of member is higher than non-member, 55,517.220 and 33,147.73 VND/ha, respectively (see Figure 1).

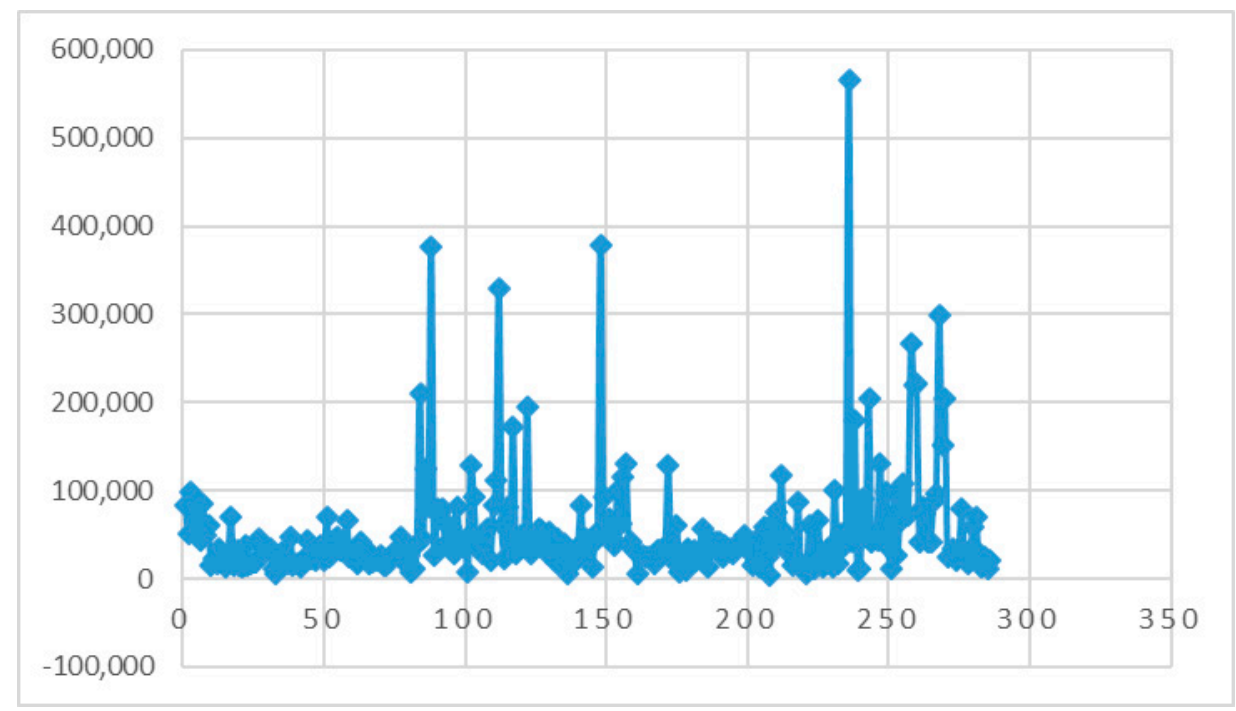

Figure 1. Net farm income of members in Vietnam Tea Association. Source: author's survey (2019).

Table 4 presents the results of the tobit model on the income of tea farms. The variables, which are association membership, education, tea area, tea price, ethnicity, experience, and share of tea sold out of total production, have meaning in explaining the impact of membership to farmer's income.

Table 4. Effect of farmer association membership on farm income.

\begin{tabular}{cccc}
\hline Variables & Coefficients & SE & $p$-Value \\
\hline Association membership & 0.166 & 0.167 & 0.000 \\
Education & 0.137 & 0.005 & 0.075 \\
Tea area & 0.292 & 0.004 & 0.018 \\
Tea price & 0.403 & 0.018 & 0.051 \\
Ethnicity & 0.225 & 0.010 & 0.062 \\
Experience & 0.189 & 0.051 & 0.038 \\
Share of tea sold & 0.845 & 0.002 & 0.870 \\
Constant & 0.747 & 0.054 & 0.008 \\
Number of observations & 742 & & \\
R-squared & 0.717 & & \\
\hline
\end{tabular}

Source: author's survey (2019).

The finding affirms the impact of membership has statistical significance $(p<0.05)$ and positive to farmers' income (dependent variable). In Table 4, test F of regressive has a meaning, which shows that there is no error in selection. By participating associations, farmers can increase their income considerably from tea-producing; in particular, membership will raise the income by 0.166 units per ha. Previous studies have echoed our conclusion on the role of farmers' associations. Emmanuel (Tolno et al. 2015) has proved the membership has increased the income for potato farmers in Middle Guinea. Van Hung et al. (2019) have concluded that association has positive impacts on rice farmers in Vietnam.

The other factor affected to farmers' income is the share of tea sold out of total production with the rate of 0.845 unit from tea production $(p<0.05)$; farmers will make effort to maximize their income by raising the share of tea sold. It is noted that greater income from tea production can result from some 
factors including higher tea price, larger selling volume or higher productivity. Moreover, the finding indicates that tea price has a statistic meaning and influence positively to farm income (0.403).

According to the results of model estimation, the increase of 1 ha in the tea-cultivated area will lead to an increase of 0.292 units of farm income. This can be explained by the efficiency of agricultural land will enable to generate higher productivity, consequently, raise the income from tea farming. Similarly, the efficiency of education and experience have influenced remarkably to farmers' income (0.137 and 0.189 , respectively).

Moreover, in Vietnam, a household can hold a multi-membership at the same time. The estimated result confirms that multi-membership can have a positive impact. If a household joins more than one association, the income impact from tea price jumps from 0.587 to 0.736 , tea area also improves from 0.044 to 0.135 (Table 5) These factors will have a positive impact on household income thanks to multi-membership will enable farmers to utilize agricultural supports and services offered by associations.

Table 5. Comparison of the impact regarding multi-membership on household income.

\begin{tabular}{ccccc}
\hline \multirow{2}{*}{ Variables } & \multicolumn{2}{c}{ Single Membership } & \multicolumn{2}{c}{ Multi-Membership } \\
\cline { 2 - 5 } & Coefficient & SE & Coefficient & SE \\
\hline Education & $0.100^{*}$ & 0.008 & $0.680^{*}$ & 0.002 \\
Tea area & $0.044^{*}$ & 0.009 & $0.135^{*}$ & 0.019 \\
Tea price & $0.587^{* * *}$ & 0.001 & $0.736^{*}$ & 0.001 \\
Ethnicity & $0.366^{*}$ & 0.015 & $0.527^{*}$ & 0.019 \\
Experience & $0.013^{*}$ & 0.001 & $0.093^{*}$ & 0.001 \\
Constant & $0.238^{*}$ & 0.094 & $0.816^{*}$ & 0.005 \\
Number of observations & \multicolumn{2}{c}{141} \\
R-squared & \multicolumn{2}{c}{0.401} \\
\hline
\end{tabular}

Note: robust standard errors in parentheses. ${ }^{* * *} p<0.01,{ }^{*} p<0.1$. Source: author's survey (2019).

\section{Conclusions}

In summary, as can be seen from the model's results, associations play an essential role in helping tea farmers to gain access to agricultural support and credit services, which in turn enable to increase income for them. Therefore, associations can be considered as an important factor in the effort of hunger elimination and poverty reduction in Vietnam. From the research findings, it can be concluded that the impact factors of the decision to join associations and of farm income including:

First, the positive factors including education, experience, labor used, tea price, tea age, tea area, farm size, ethnicity, region, extension service and credit access which are likely to affect to the willingness to join an association, however, gender, age are negative.

Second, to evaluate determinant factors on household income, the finding shows that association membership has a statistic significance and positive impact on the income $(0,166)$. Moreover, it also concludes that farm income is considerably influenced by tea price and share of tea sold and tea area. The estimation on impact factors of household income indicates that association members can gain a higher net profit than the non-member; the estimated results confirm the difference in the statistical significance of net profit earned by the member and the non-member.

These research findings prove that tea farm associations can offer their members some benefits, e.g., supply information about the products' inputs and outputs' markets, provide agricultural support services, organizing training course, and connecting to credit schemes; as a result, these enable farmers to increase their productivity, income and contribute to improving the living standards. From the policy aspect, this movement is vital because if associations follow the market-oriented production, which will assist to the process of economic mechanism transition in the rural area to the more enlightened, toward the context of current international integration. 
As a result, in the next few years, there are more solutions need to be created to promote the efficiency of tea farmers' associations:

Strengthen associations who can offer actual support services to their members rather than hypothetical organizations. To realize this aim, associations should focus on support services on the factors which have positive impacts on member income, i.e., how to use labor effectively, subsidy to tea price, and increase the share of tea sold and tea area.

Associations should focus on providing up-skill training, enriched knowledge, the aim and objective of associations matching with characteristics, features of socioeconomic and job-related organizations rather than governmental agencies, especially for management levels. In terms of training contents, they might need to provide some courses or workshops related to methods of trade promotion, updated information on regulations and markets, market prices, and labor information to their members.

Associations should especially focus on making exploitation and take responsibility to explain their activities, e.g., financial reports for organizations which use the capital contributed by their members. Explicit financial reports can become one of the most important conditions to build trust with their members and sponsors.

However, similar to other studies, there are some limitations to ours. Our study mainly focuses on test the role of association with tea farmers in building networking for associations. It has not considered the newly emerging factors in the tea industry in Vietnam, i.e., factors related to producing processes that are applying either high-tech farming techniques or/and certified farming standards (e.g., Vietgap and Globalgap). In Vietnam, associations have studied these factors to advise their members in applying them in production and can increase production efficiency. In the meantime, this is the second stage of the research project to study the role of associations to the models of producing units applied to high-tech farming in the Fourth Industrial Revolution 4.0, which has been occurring in Vietnam.

Author Contributions: Formal analysis, H.V.V. and H.H.; Investigation, H.H.; Methodology, H.V.V. and H.H.; Project administration, H.V.V.; Writing—original draft, H.V.V., H.H., Q.H.L.; Writing—review and editing, H.V.V., H.H., and Q.H.L. All authors have read and agreed to the published version of the manuscript.

Funding: This research received no external funding.

Conflicts of Interest: The authors declare no conflict of interest.

\section{Appendix A}

Table A1. Summary of key characteristics of organizations in the Vietnamese tea industry.

\begin{tabular}{|c|c|c|c|c|c|}
\hline No. & Association & Legal Status & $\begin{array}{c}\text { Conditions to Become a } \\
\text { Member }\end{array}$ & Strong Support Services & $\begin{array}{c}\text { Limitation/Weakness } \\
\text { Barriers }\end{array}$ \\
\hline 1 & $\begin{array}{l}\text { Vietnamese } \\
\text { farmers } \\
\text { association }\end{array}$ & $\begin{array}{l}\text { A sociopolitical } \\
\text { organization } \\
\text { managed by } \\
\text { the government }\end{array}$ & $\begin{array}{l}\text { Vietnamese farmers or } \\
\text { employees in the } \\
\text { agriculture-related areas. }\end{array}$ & $\begin{array}{l}\text { The government provides } \\
\text { funding, technology, } \\
\text { information, training } \\
\text { courses }\end{array}$ & $\begin{array}{l}\text { Procedure and } \\
\text { application process to } \\
\text { get support are } \\
\text { time-consuming and } \\
\text { bureaucratic. }\end{array}$ \\
\hline 2 & VITAS & $\begin{array}{l}\text { Organization } \\
\text { for citizens and } \\
\text { organization in } \\
\text { the tea industry }\end{array}$ & $\begin{array}{c}\text { Farmers are in the same } \\
\text { industry and interests and } \\
\text { voluntary to become a } \\
\text { member }\end{array}$ & $\begin{array}{c}\text { Good at connecting, } \\
\text { supporting trade and } \\
\text { members to become a } \\
\text { stakeholder in supply chains }\end{array}$ & $\begin{array}{l}\text { All aid and the right } \\
\text { protection for members } \\
\text { are based on a voluntary } \\
\text { and non-profit basis; a } \\
\text { loosen connection, low } \\
\text { legal status. }\end{array}$ \\
\hline 3 & Co-ops & $\begin{array}{l}\text { An enterprise } \\
\text { owned and } \\
\text { controlled by a } \\
\text { group using } \\
\text { services } \\
\text { provided by the } \\
\text { co-op staffs or } \\
\text { members. }\end{array}$ & $\begin{array}{l}\text { There is a need to } \\
\text { collaborate among } \\
\text { members and use co-op } \\
\text { products and services. } \\
\text { Fill an application form and } \\
\text { agree with the co-op rules. } \\
\text { Share is required } \\
\text { (not more than } 20 \% \text { of } \\
\text { registered capital) }\end{array}$ & $\begin{array}{l}\text { Create new jobs for its } \\
\text { members, but also more } \\
\text { beneficial conditions for } \\
\text { producing and processing. } \\
\text { A co-op is organized as a } \\
\text { shareholder company, in } \\
\text { which all members will } \\
\text { receive a profit share based } \\
\text { on the company's revenue } \\
\text { and its shareholders. }\end{array}$ & $\begin{array}{l}\text { Members have to } \\
\text { contribute a share, which } \\
\text { is a barrier for poor } \\
\text { farmers. }\end{array}$ \\
\hline
\end{tabular}


Table A2. Descriptive statistics of respondents.

\begin{tabular}{|c|c|c|c|c|c|}
\hline \multicolumn{2}{|c|}{ Continuous Variables } & $\begin{array}{l}\text { Association } \\
\text { Members }\end{array}$ & Non-Members & $t$-Statistic & $p$-Value \\
\hline \multicolumn{2}{|l|}{ Age } & 47.65 & 36.52 & 0.600 & 0.004 \\
\hline \multicolumn{2}{|l|}{ Education } & 11.13 & 10.84 & 0.381 & 0.594 \\
\hline \multicolumn{2}{|l|}{ Family size } & 4.93 & 4.92 & 0.671 & 0.216 \\
\hline \multicolumn{2}{|l|}{ Family labor } & 3.85 & 3.84 & 0.135 & 0.752 \\
\hline \multicolumn{2}{|l|}{ Farm size } & 0.79 & 0.74 & -0.211 & 0.532 \\
\hline \multicolumn{2}{|l|}{ Tea age } & 20.21 & 20.74 & 0.547 & 0.460 \\
\hline \multicolumn{2}{|l|}{ Experience } & 14.93 & 12.33 & 0.330 & 0.566 \\
\hline \multicolumn{2}{|l|}{ Tea area } & 0.76 & 0.71 & 0.058 & 0.591 \\
\hline \multicolumn{2}{|l|}{ Distance to road } & 1.51 & 1.48 & 0.762 & 0.428 \\
\hline \multicolumn{2}{|l|}{ Hired labor } & 5.59 & 4.70 & 0.780 & 0.678 \\
\hline \multicolumn{2}{|c|}{ Distance to market } & 2.40 & 2.43 & 0.541 & 0.721 \\
\hline \multicolumn{2}{|c|}{ Share of tea sold } & 88.40 & 67.25 & 0.035 & 0.002 \\
\hline \multicolumn{2}{|l|}{ Tea price } & 20.75 & 19.71 & 3.955 & 0.001 \\
\hline \multicolumn{2}{|l|}{ Off-farm income } & 2611.47 & 2015.09 & -0.559 & 0.259 \\
\hline \multicolumn{2}{|c|}{ Categorical variables } & $\%$ & $\%$ & $\mathrm{X}^{2}$ statistic & $p$-value \\
\hline \multirow{2}{*}{ Gender } & Male & 88.0 & 76.2 & \multirow{2}{*}{1.760} & \multirow{2}{*}{0.001} \\
\hline & Female & 12.0 & 23.8 & & \\
\hline \multirow{2}{*}{ Marital status } & yes & 89.4 & 91.3 & \multirow{2}{*}{0.046} & \multirow{2}{*}{0.965} \\
\hline & no & 10.6 & 8.7 & & \\
\hline \multirow{2}{*}{ Land owned } & yes & 54.0 & 56.0 & \multirow{2}{*}{-1.210} & \multirow{2}{*}{0.455} \\
\hline & no & 46.0 & 44.0 & & \\
\hline \multirow{2}{*}{ Extension access } & yes & 94.7 & 17.4 & \multirow{2}{*}{21.001} & \\
\hline & no & 5.3 & 82.6 & & 0.001 \\
\hline & yes & 86.2 & 12.1 & 16810 & 0005 \\
\hline Credit cara & no & 14.8 & 88.9 & 16.810 & 0.005 \\
\hline Ethnicity & yes & 82.7 & 5.8 & 3167 & 0000 \\
\hline Еtकाषाty & no & 17.3 & 94.2 & $3.16 /$ & 0.000 \\
\hline Communist Party & yes & 53.8 & 13.1 & & \\
\hline Member & no & 46.2 & 86.9 & 2.656 & 0.000 \\
\hline & yes & 21.8 & 16.6 & 8170 & \\
\hline Red River Delta & no & 79.2 & 83.4 & $8.1 / 0$ & 0.04 \\
\hline Northern Midlands and & yes & 82.7 & 26.3 & & \\
\hline Mountains & no & 17.3 & 73.7 & 19.209 & 0.000 \\
\hline North Central and & yes & 61.5 & 93.9 & & \\
\hline Central Coast & no & 38.5 & 6.2 & 25.732 & 0.000 \\
\hline & yes & 7.7 & 50.9 & & \\
\hline Highlands & no & 92.3 & 49.1 & 30.641 & 0.002 \\
\hline
\end{tabular}

\section{References}

Abdulahi, Taiwo Olabisi, Ugochukwu Udunze, and Obianuju Emmanuela Agbasi. 2015. Effect of Cooperative Membership on the Economic Empowerment of Women in Osun State of Nigeria. International Journal of Business and Economics Research 4: 21-29. [CrossRef]

Adewakun, A. 2012. Cooperative as a tool for enhancing financial inclusion. African Newspaper of Nigeria 1.

Ates, Hacer Celik, and Mustafa Terin. 2011. Farmers' perceptions of farmer organizations in rural areas. African Journal of Business Management 5: 179-86.

Baah, Francis. 2008. Harnessing farmers' associations as channels for enhanced management of cocoa holdings in Ghana. Scientific Research and Essays 3: 395-400. 
Bachke, Maren Elise. 2009. Are Farmers' Organizations a Good Tool to Improve Small-Scale Farmers' Welfare? Paper presented at Nordic Conference in Development Economics, Oscarsborg, Norway, June 18-19.

Bernard, Tanguy, Alemayehu Seyoum Taffesse, and Eleni Gabre-Madhim. 2008. Impact of cooperatives on smallholders' commercialization behaviour: evidence from Ethiopia. Agricultural Economics 39: 147-61. [CrossRef]

Chung, Kim Chu, and Thanh Mai Cuc. 2018. Some solutions for developing sustainable raw materials tea production in Phu Tho province, Vietnam. The Journal of Agricultural Science 16: 85-94.

Do, Quang Giam. 2013. Evaluating Probability of Joining Contract Farming of Farmer in Northern Hilly and Mountainous Region: A case Study of Tea Farmer in Tuyen Quang Province. Journal of Scientific Research and Development 11: 447-57.

Ebrahim, Endris, Haji Jema, and Tegegne Bosena. 2020. Factors Affecting Vegetable Producers Market Outlet Choice in Case of Habru District, North Wollo Zone, Ethiopia. European Business \& Management 6: 1-9.

Ekepu, D., and N. Tirivanhu. 2017. Assessing farmer involvement in collection action for enhancing the sorghum value chain in Soroti, Uganda. South African Journal of Agricultural Extension 45: 118-30.

Fisher, Elisabeth, and Matin Qaim. 2012. Linking Smallholders to Markets: Determinants and Impacts of Farmer Collective Action in Kenya. World Development 40: 1255-68. [CrossRef]

General Statistics Office of Vietnam (GSO). 2019. Statistical Yearbook; Hanoi: General Statistics Office of Vietnam (GSO).

Gomina, Abel. 2013. Impact Analysis of Savings and Credit Cooperative Societies in combating Poverty among Crop Farmers in three Local Government Areas of Niger State, Nigeria. Zaria: The School of Postgraduate Studies, Ahmadu Bello University.

Hellin, Jon, Mark Lundy, and Madelon Meijer. 2009. Farmer organization, collective action and market access in Meso-America. Food Policy 34: 16-22. [CrossRef]

Ho, Que Hau. 2014. The role of socio-Professional organizations for economic development after 30 years of change. Development Economic Journal 208: 2-8. (In Vietnamese).

Idowu, James, and Olayide Oladeji. 2019. Agriculture Co-operative Associations, Livelihood Income and Rural Households Welfare in Osun State, Nigeria. Greener Journal of Agricultural Sciences 9: 180-88.

Le, Van Son. 2005. The Role of Non-Governmental Organizations in Technical Assistance, Capacity Building for People in the Northern Midlands Region. Hanoi: Vietnam National University.

Le, Xuan Thai. 2014. Factors affecting farm household income in rice production models in Vinh Long province. Journal of Science 35: 79-86.

Mohamed, Paul Ngegba, and David Allieu Mansaray. 2016. Evaluating the effectiveness of farmers' associations in facilitating clientele involvement in agriculture development programmes in port Loko district, Northern Sierra Leone. International Journal of Advanced Biological Research 6: 92-105.

Mpiira, S., B. Kiiza, E. Katungi, C. Staver, J. Tabuti, M. Kyotalimye, P. Muwumba, E. Karamura, and W. Tushemereirwe. 2013. Factors influencing households' participation in the Savings and Credit Cooperative (SACCO) programmes in Uganda. African Journal of Agricultural Research 8: 5280-88.

Muchopa. 2011. Evaluating Performance by Cooperative Value and Efficiency. Nigerian Journal of Cooperative Studies 2: 39-54.

Mwaura, Francis. 2014. Effect of Farmer Group Membership on Agricultural Technology adoption and Crop Productivity in Uganda. African Crop Science Journal 22: 917-27.

Nam, Vu. 2017. Development of tea Villages in Thai Nguyen Province by Sustainability. Ph.D. thesis, Thai Nguyen University, Thái, Nguyên.

Nguyen, Quoc Nghi, and Bui Van Trinh. 2011. Factors affecting the income of ethnic minorities in the Mekong Delta. Journal of Science 18: 240-50.

Nguyen, Viet Anh, Thu Thuy Tran, and Kien Nguyen. 2010. Factors affecting the income of borrowed farmer households in Quang Trach district, Quang Binh province. Journal of Science 62: 20-23.

Nguyen, Hai Dang, Thanh Ngo, Tu Le, Hunog Ho, and Hai T. H. Nguyen. 2019. The role of knowledge in sustainable agriculture: Evidence from farms' technical efficiency in Hanoi, Vietnam. Sustainability 11: 2472. [CrossRef]

Nkechi, Cordelia Ojiagu, and Onugu Charles. 2015. Uchenna. Effects of membership of cooperative organisations and determinants on farmer-members' income in rural Anambra State, Nigeria. International Journal of Scientific and Technology Research 4: 28-35. 
Oxfarm. 2017. Renovate and Support Production Development and Agricultural Extension towards Poverty Reduction in Ethnic Minority Areas. Hanoi: Hong Duc Publishing House.

Pham, Hung. 2017. Disclosure the Subject Role of Personnel in New Rural Construction in Cuu Long. Ho Chi Minh Viet Nam: National Political Academy.

Sheilla, Jeruto Tallam, Kibet Tanui Joseph, Joan Muller Alice, Manyuru Mutsotso Beneah, and Gasper Mowo Jeremias. 2015. The influence of organizational arrangements on effectiveness of collective action: Findings from a study of farmer groups in the East African Highlands. Journal of Agricultural Extension and Rural Development 1: 151-65.

Simonović, Zoran. 2016. Cooperatives and farmers association as a model of entrepreneurship in Serbian agriculture regarding the case of Nisava district cooperatives and farmers association as a model of entrepreneurship in Serbian agriculture regarding the case of Nisava district. Economics of Agriculture 2: 699-712.

Tolno, Emmanuel, H. Kobayashi, Matsumura Ichizen, M. Esham, B. S. Balde, and S. Lanka. 2015. Economic Analysis of the Role of Farmer Organizations in Enhancing Smallholder Potato Farmers' Income in Middle Guinea. Journal of Agricultural Science 7: 3. [CrossRef]

Tran, Dai Nghia. 2008. An Analysis of Economic and Environmental Impacts for the Transition to Organic Tea Production in Thai Nguyen Province of Vietnam. Ph.D. thesis, the University of Hawaii at Manoa, Honolulu, HI, USA.

Tran, Hung. 2017. Global Tea Industry Value Chain and the Involvement of Vietnam. Ha Noi: University of Economics and Business-Vietnam National University.

Tran, Tai Anh, Tuyen Quang Tran, Nu The Tran, and Hai Thi Nguyen. 2018. The role of education in the livelihood of households in the Northeast region, Vietnam. In Education Research for Policy and Practice. Berlin and Heidelberg: Springer.

Valaskova, Katarína, Pavol Durana, Peter Adamk, and Jaroslav Jaros. 2020. Financial Compass for Slovak Enterprises: Modeling Economic Stability of Agricultural Entities. Journal of Risk and Financial Management 13: 92. [CrossRef]

Van Hung, Vu, Ho Huong, and Hoi Le Quoc. 2019. Impact of farmer education on production efficiency: The case of rice farms in Vietnam. Management Science Letters 9: 1909-18.

Publisher's Note: MDPI stays neutral with regard to jurisdictional claims in published maps and institutional affiliations.

(C) 2020 by the authors. Licensee MDPI, Basel, Switzerland. This article is an open access article distributed under the terms and conditions of the Creative Commons Attribution (CC BY) license (http://creativecommons.org/licenses/by/4.0/). 